\title{
Poetry as Antidote to Toxic Certainty
}

\author{
Matt Kershaw \\ Yale Divinity School (New Haven, CT)
}

\begin{abstract}
In examining the discursive environment surrounding the Great War (1914-1918), one finds a familiar reduction of reality into flat and mutually exclusive binaries written in what Robert Graves called "Newspaper Language." In this article, I suggest such discursive flattening to be both unproductive and dehumanizing, employing the term "toxic certainty" to refer to language used by a given partisan over and against the perceived other, where the rhetorical force of an assertion is taken to be the proof of that assertion. To counter dehumanizing discourse both in and out of the pulpit, I suggest a remedy in an alternate reading of James 1:22, where preachers can aspire to be "poets of the word, "rather than just self-deceiving hearers. This idea is developed through an examination of the poetic efforts to humanize the full reality of the Great War undertaken by Wilfred Owen and Siegfried Sassoon.
\end{abstract}

\section{Text}

\section{Toxic Certainty: Rhetorical Force Over and Against the Other}

In August of 1916, at the height of the Great War, an editorial appeared in the Morning Post of London entitled "A Mother's Answer to 'A Common Soldier."' It was a powerful and broadly resonant call to action against its perceived enemy: the pacifist sentiments of a wounded soldier who had called for peace in the same column space just a few days before. The letter is quite rousing:

"As the mother of an only child — a son who was early and eager to do his duty — may I be permitted to reply to Tommy Atkins... ${ }^{1}$ Perhaps he will kindly convey to his friends in the trenches, not what the Government thinks, not what the Pacifists think, but what the mothers of the British race think of our fighting men. It is a voice which demands to be heard, seeing that we play the most important part in the history of the world, for it is we who 'mother the men' who have to uphold the honour and traditions not only of our Empire but of the whole civilized world."

\footnotetext{
${ }^{1}$ A generic nickname for an anonymous British soldier.

${ }^{2}$ Quoted in Robert Graves, Good-bye to All That, (New York: Vintage International, 1985), 228-229.
} 


\section{KERSHAW: POETRY AS ANTIDOTE TO TOXIC CERTAINTY}

Her passion is admirable, and she utilizes the rhetorical pulpit of a bereaved mother to underscore her authority on matters of justice and war, calling for victory at any cost to honor the memory and sacrifice of her son. From the vantage point of certainty:

There is only one temperature for the women of the British race, and that is white heat. With those who disgrace their sacred trust of motherhood we have nothing in common. Our ears are not deaf to the cry that is ever ascending from the battlefield from men of flesh and blood whose indomitable courage is borne to us, so to speak, on every blast of the wind. We women pass on the human ammunition of 'only sons' to fill up the gaps, so that when the 'common soldier' looks back before going 'over the top' ${ }^{3}$ he may see the women of the British race at his heels, reliable, dependent, ${ }^{4}$ uncomplaining. ${ }^{5}$

This letter received immediate and wide approbation. Typical responses read: "[The letter is o]ne of the grandest things ever written, for it combines a height of courage with a depth of tenderness which should be, and is, the stamp of all that is noblest in human nature." ${ }^{\prime 6}$ Similarly, A different Bereaved Mother echoed the sentiment: "I have lost my two dear boys, but since I was shown the 'Little Mother's' beautiful letter a resignation too perfect to describe has calmed all my aching sorrow, and I would now gladly give my sons twice over." ${ }^{\prime 7}$ Both responses complement the sentiments of the Queen, who "was deeply touched at the 'Little Mother's' beautiful letter ... Her Majesty fully realizes what her words must mean to our soldiers in the trenches and in hospitals." No doubt about it, the 'Little Mother's' courage is galvanizing, her rhetoric effective, and the moral authority that derives from her own contribution and sacrifice merits due weight and consideration on the part of her readers. We are rightly inspired by her passion.

\footnotetext{
${ }^{3}$ Referring to a charge from the trenches. Going over the top meant exposing oneself to machine gun fire.

${ }^{4}$ I assume in modern vernacular this should read "dependable," but it is interesting to read both ways.

${ }^{5}$ Graves, Good-bye, 229.

${ }^{6}$ Graves, 231. Graves identifies the speaker as an anonymous "soldier in France"

${ }^{7}$ Graves, 231.

${ }^{8}$ Graves, 228.
} 


\section{KERSHAW: POETRY AS ANTIDOTE TO TOXIC CERTAINTY}

Nearly a year later, the soldier-poet Siegfried Sassoon published opposite arguments with identical passion. Since his letter-published in a different paper-is a bit shorter than the 'Little Mother's,' I quote in toto:

Finished with the War

A Soldier's Declaration

I am making this statement as an act of wilful defiance of military authority, because I believe that the war is being deliberately prolonged by those who have the power to end it.

I am a soldier, convinced that I am acting on behalf of soldiers. I believe that this war, upon which I entered as a war of defence and liberation, has now become a war of aggression and conquest. I believe that the purposes for which I and my fellow-soldiers entered upon this war should have been so clearly stated as to have made it impossible to change them, and that, had this been done, the objects which actuated us would now be attainable by negotiation.

I have seen and endured the sufferings of the troops, and I can no longer be a party to prolong these sufferings for ends which I believe to be evil and unjust.

I am not protesting against the conduct of the war, but against the political errors and insincerities for which the fighting men are being sacrificed.

On behalf of those who are suffering now I make this protest against the deception which is being practised on them; also I believe that I may help to destroy the callous complacence [sic] with which the majority of those at home regard the continuance of agonies which they do not share, and which they have not sufficient imagination to realize. S. Sassoon. ${ }^{9}$

Sassoon utilizes a similar kind of rhetorical credibility-one borne of suffering experienced firsthand - to establish his point, and to rouse the public imagination to sympathy with his views. It is interesting that both letters show similar means utilized to utterly divergent ends. It is also interesting that both letters shared a loud and gleeful reception among the respective partisans of their policy positions. But it is most interesting that both letters presuppose two things: first, that the writer speaks for everybody, and second, that the force of their assertion equals the proof of that assertion. These two presuppositions can also be applied to preaching, since a homily that

\footnotetext{
${ }^{9}$ Siegfried Sassoon, "Finished with the War: A Soldier's Declaration," Bradford Pioneer, July 27, 1917.
} 


\section{KERSHAW: POETRY AS ANTIDOTE TO TOXIC CERTAINTY}

doesn't speak for everyone and doesn't stand on the force of its own argument could easily be seen as a waste of time. But forceful homilies, much like the forceful letters cited, do little but excite the partisans on either side of an issue. The result is hard hearts and toxic —or eventually emptypews. It is a preacher's worst nightmare to exude mere sound and fury, or to be reduced to the inarticulate clang of tinkling cymbals or sounding brass (1 Cor. 13:1); it is telling that in the opening pages of Sherston's Progress - the third in Sassoon's trilogy of semi-autobiographical novels - Sassoon reflects on the actual results of his letter: "As far as I was concerned the only visible result was a batch of letters from people who either agreed or disagreed with my views."10

As passionate as Sassoon must have been to write and publish that letter (he risked his career and life to do so), it was ineffective. Even through the white heat of passionate belief maintained long after the war, he eventually came to disavow it. The final line of the letter, however, articulates a key insight not provided by the little mother that drew my attention: "I believe that I may help to destroy the callous complacence [sic] with which the majority of those at home regard the continuance of agonies which they do not share, and which they have not sufficient imagination to realize." The reality which Sassoon failed to fully articulate in his letter was simply not accessible in the "newspaper language" of rhetorical force and aggressive ${ }^{11}$ assertion. In asserting against the content of "Little Mother" and other partisans like her, he assented to their discursive norms, perpetuating the rhetorical trench warfare of his - and ourtimes. The resulting trade of barrages is what I am calling toxic certainty: discursive acts asserted over and against the other with a certainty that disregards the human reality of the "no man's land" of real suffering between partisan trenches.

\footnotetext{
${ }^{10}$ Siegfried Sassoon, Sherston's Progress, (New York: Penguin, 2013), 5. Emphasis mine.

${ }^{11}$ And almost always partisan-polemic...
} 


\section{KERSHAW : POETRY AS ANTIDOTE TO TOXIC CERTAINTY}

\section{Poiētai Logou: The Case for Sassoon and Owen}

The thought conjures a reading from scripture: "Be doers of the word, and not merely hearers who deceive themselves"(James 1:22 NRSV). Encountering the Greek text of this passage recently, I was struck by the wording "Ginesthe de poiêtai logou kai mē akroatai monon

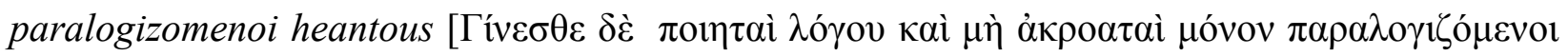
$\dot{\varepsilon} \alpha v \tau o u ́ \varsigma]$." In every sermon I've heard on this passage, this text is used to demarcate the distance between hearing and action, seeking to undermine the hypocritical human tendency to equate the hearing of the Gospel and the living of it. But it is the word here translated "doers," poiettai, that suggests an alternate rendering: Be makers, or creators of the word, and not just hearers. I will suggest more boldly the acoustically resonant "poets of the word." Any number of exegetical exercises on this rendering may bear fruit in other directions, but I would like to propose Sassoon and his fellow soldier-poet Wilfred Owen as striking examples of poiētai logou. Such a shift in interpretation creates new spaces of discipleship, with changed possibilities of living the Gospel when one rejects either the "newspaper language"12 cited above or the inaccessible technical language of dogmatics, and instead pursues the exegetical norms and lived realities ${ }^{13}$ of poesy and creative language. These norms have high potential to reimagine the lived Gospel in stark contrast to the discursive norms of certainty, what we might call "preachiness." These norms of "preachiness" effectively enforce a distance between preacher and congregation, and use certainty to steamroll discourse into flat, untenable binaries of absolute right and wrong, truth and falsehood, virtue and vice, and so on. This steamroller does more than force all discourse into its own assumptions and norms; it flattens the humanity out of a congregation of men and women made in

\footnotetext{
${ }^{12}$ It is striking that Sassoon came to hate newspapers in general after the war. Cf. his satirical poem found in Siegfried Sassoon, "Lines Written in Anticipation of a London Paper Attaining a Guaranteed Circulation of Ten Million Daily," Collected Poems 1908-1956, (London, Faber \& Faber, 2002), 121-23.

${ }^{13}$ True poietai logou would aggressively resist the separation of exegetical norms and lived realities.
} 


\section{KERSHAW : POETRY AS ANTIDOTE TO TOXIC CERTAINTY}

the image of God and forces the Gospel—broadly conceived-into flat categories of pragmatic impossibility that are as "certain" as they are divorced from lived experience. This violent hermeneutical assumption — so prevalent in the polemic of both pulpit and academy — amounts to a discursive norm measured by its potency to affiliate and alienate: toxic certainty.

In contrast to this discursive norm, poetry and its adherents, the poietai logou, subvert these norms by assuming that the ground of primary truth does not lie in absolute binaries of certainty, but rather in the primary reality of the individual lived experience. Much lyric poetry operates in this latter mode by the implicit voice of lyric, what scholars refer to as the "lyric "I'"14 which sanctifies the unstable ground of lived experience and has little need for certainty. Siegfried Sassoon and Wilfred Owen both illustrate and demonstrate this point. Both poiētai logou and the poetry they created rose from the trenches of the First World War through traumatic extremes of experience. Although both would probably deny it at the time, I submit that both succeeded in creating a "word" that sought to mediate the revelation of sacred humanity by poetically sanctifying their own experience of the hell of war for themselves and for those they came to love in that hell. ${ }^{15}$

One of Owen's strategies is to articulate toxic certainty in terms of emotional distance. In the final stanza of "Insensibility," he articulates a contrast between the distance of certainty and the intimacy of poetry:

But cursed are dullards whom no cannon stuns

That they should be as stones

${ }^{14}$ Cf. Scott Brewster, Lyric, (New York: Routledge, 2009), 30-34.

${ }^{15}$ Consider the line from Owen's "The Calls:"

For leaning out last midnight on my sill

I heard the sighs of men, that have no skill

To speak of their distress, no, nor the will!

A voice I know. And this time I must go.

Wilfred Owen, "The Calls," Wilfred Owen: The Complete Poems and Fragments, Vol. 1, ed. Jon Stallworthy (London: Chatto \& Windus, 2013), 162-63. 
Wretched are they, and mean

With paucity that never was simplicity.

By choice they made themselves immune

To pity and whatever moans in man

Before the last sea and the hapless stars;

Whatever mourns when many leave these shores;

Whatever shares

The eternal reciprocity of tears. ${ }^{16}$

The "dullard" in question is the archetypal English "patriot" who chose to subsume all data about the war into indignant nationalism or naive or hostile pacifism - the inescapable binaries of the "newspaper language" at the time. Owen had little patience for the tourist of the trenches, the newspaper scholar of the conflict who knew the war by maps, and even less patience for the eloquent blowhards who talked much but fought little, if at all. Such "scholars" would exhaust both their lungs, ink ribbons, and the Oxford Thesaurus vaunting the virtue and vindicating the valorous and virtuous victors fighting for King and Country, enunciating the utter and unquestionable necessity of the war, and singing the blindingly trite praise of "fallen heroes" who were to him equal parts sacrosanct and nameless. All such "heroes" died gloriously by default in the eyes of such dullards. From this kind of dullard's point of view even mourning the dead became a kind of sacrilege to sacred patriotism. The steamrolling of humanity becomes apparent in such attitudes, where only the glorious annihilating of the rampaging hun and its end-victorymattered. The means, all of those who had names, families, ambitions, faults, loves, fears, and lives were a distant second in priority to the certain absolute justice of their cause.

Thus jingoistic patriotism became the new orthodoxy, enforced with the full weight of social pressure of mass media supporting a dominant narrative. This orthodoxy viewed the world and all of its inhabitants as a faceless mass characterized only by its relevance to the cause of "with

\footnotetext{
${ }^{16}$ Wilfred Owen, “Insensibility," Complete Poems, 145-47.
} 


\section{KERSHAW : POETRY AS ANTIDOTE TO TOXIC CERTAINTY}

us or against us." All discourse was interpreted and valued only as it related to one or the other side of a single issue. Thus a single narrative, in this case the war viewed a certain way, dominated the entire discursive landscape, reducing all voices to variations on a single theme: for-or against — the war. That fact ignored the more salient points of deep human reality, principally the staggering scale of loss the war generated in terms of fathers, sons, brothers, and the decimation of innocent men, women, and children in its theaters. Both Owen and Sassoon were acutely aware that such dominant narratives always steamroll the humanity out of the vast majority of people who exist incidentally to or unwittingly within that narrative. As Owen articulates, the power of just such narrative hegemony constitutes the choice to render its adherents, particularly the powerful ones, immune to pity and whatever moans, or mourns, in man.

Following Owen's lead, let's take a look at a much more emotionally intimate poem, Siegfried Sassoon's “Attack:”

At dawn the ridge emerges massed and dun In the wild purple of the glow'ring sun Smouldering through spouts of drifting smoke that shroud The menacing scarred slope; and, one by one, Tanks creep and topple forward to the wire. The barrage roars and lifts. Then, clumsily bowed With bombs and guns and shovels and battle-gear, Men jostle and climb to meet the bristling fire. Lines of grey, muttering faces, masked with fear, They leave their trenches, going over the top While time ticks blank and busy on their wrists, And hope, with furtive eyes and grappling fists Flounders in mud. O Jesus, make it stop! ${ }^{17}$

The narrative vignette supplied by the poem is thrown into an irruptive spin by a shift in mood: We move from observers in the objective-descriptive into a shared emotional space with the

\footnotetext{
${ }^{17}$ Siegfried Sassoon, “Attack,” Collected Poems, 65.
} 


\section{KERSHAW : POETRY AS ANTIDOTE TO TOXIC CERTAINTY}

stumbling, terrified soldier with the subjective-vocative "O Jesus, make it stop!" This move splits the poem in two, contrasting the cultivated expectations of the oddly picturesque beginning of the poem with the scream of a man. Is he a coward? If so, are you and I as readers participating in cowardice? Or does the poem subvert the forced binary of courage and cowardice? As creations of a word maker, Sassoon's attackers transcend that binary: they are human. The cause and the certainty of justice or injustice is subverted as we see the reality more clearly: muttering, fearful faces laden with poorly balanced loads, stumbling and wading through mud and to their violent deaths - mowed down like dandelions by machine gun fire. The attack after which the poem is named, is not a charge, it is a jostle. The moment of that jostle is potent, but time is not the valorized time of the heroic moment, but a blank and callous rhythm that promises death, dismemberment, or mercy to each soldier, seemingly at random. Perhaps most poignant is the gear list of line 7 , a mainstay of the soldier's experience unappreciated by those who have not served. Sassoon tellingly details the soldiers' gear: accoutrements of both war and labor (bombs, guns, and shovels). Sassoon poignantly elucidates the irony of trench warfare by conflating the tools of war and labor swinging from the same packs, radically reversing Isaiah's prophecy that in the last days, people will grow ignorant of the norms of war by beating their swords into ploughshares, and their spears into pruning hooks (Isa. 2:4 NRSV). Here, not only is the difference known, sword and shovel are both used in the work of death. The necessary trenches become acts of violence as the sacred space of the pastoral psalm —-Sassoon's preferred genre — is violated, desecrated. The damp furrows and ordered lines of the plowed field and fence are scarred into the tissue of war's landscape. This desecration is developed in "Prelude: The Troops," where Sassoon paints the trenches as a wasted field populated by those who might otherwise have enjoyed creation's beauty:

...these, who cling to life with stubborn hands,

Can grin through storms of death and find a gap 
In the clawed, cruel tangles of his defence.

They march from safety, and the bird-sung joy

Of grass-green thickets, to the land where all

Is ruin, and nothing blossoms but the sky

That hastens over them where they endure

Sad, smoking, flat horizons, reeking woods,

And roundered trench lines volleying doom for doom. ${ }^{18}$

\section{Poetry, Humanity, Certainty}

At this point an objection arises: aren't these just visceral examples of the "anti-war" sentiment opposed to those of the "Little Mother" and her partisans? Perhaps. Sassoon and Owen have ample credibility as anti-war poets. At least that is how they are usually introduced and classified, and there is certainly some truth to the designation. Both, without question, wanted the war to end and wrote brilliantly and with throbbing pathos about the evils of war. But is that all that these poems give us? What exactly does "anti-war" mean? What does "anti-fascist," "proTrump," "pro-choice," "anti-globalist," or any other such designation defined more by its prefix than by its content actually mean? My point is not to disavow or understate the relative virtue or wickedness of any such movements or ideas. Rather, I am suggesting such a prefix-dependent designation necessarily forces all relevant, tangential, and even incidental discourse into the binary certainty of one side or the other. We look at the horrific images and data that arise from any armed conflict and we say we are anti-war. Well and good, but we steamroll the victims of these scenes just as much as the perceived "pro-war" other against whom we assume to position ourselves. It is true that both Sassoon and Owen were opposed to what they viewed as a pointless continuation of the war, and Sassoon even risked his career - and possibly his life - to publicly disavow the morality of the continued enterprise. But both also fought in it, and fought like hell. Both saw

\footnotetext{
${ }^{18}$ Siegfried Sassoon, "Prelude: The Troops," Collected Poems, 61.
} 


\section{KERSHAW : POETRY AS ANTIDOTE TO TOXIC CERTAINTY}

plenty of heavy combat. Both killed Germans. Both were decorated for valor. Both were wounded, Sassoon three times. Both endured severe psychological trauma. And both had the opportunity to transfer to safer administrative positions after convalescing from their wounds, but both refused, opting instead to return to the trenches where Owen was killed, and Sassoon was shot in the head but survived until 1967.

The fact is, these poems, true products of poiētai logou, are too ripe a fruit to be mere proor anti-war. Owen, for instance, frequently exults in the quasi-angelic power of the soldier engaged in the full brutality of war:

$[\mathrm{P}]$ ower was on us as we slashed bones bare

Not to feel sickness or remorse of murder.

[I have] witnessed exultation-

Faces that used to curse me, scowl for scowl,

Shine and lift up with passion of oblation,

Seraphic for an hour; though they were foul. ${ }^{19}$

The poems refuse the flatness of newspaper language and the flatness of all such homiletics that assent to their norms; in contrast, they are rich, full, juicy with humanity. In order to fit strictly into the pro or anti-war binary of certainty, we would have to extract about $5 / 8$ of the humanity from both poem and poet.

In literary terms, the discursive difference could be articulated in terms of genre, but only if genre is understood in terms of function rather than form. That is to say that a given genre operates within a sphere of possibility, and its semantic content — or viewed more broadly, its meaning - is tied to the limits and priorities of the sphere of possibility (or genre) it assumes. "Newspaper language" would ideally be a genre marked by the potential to establish factual truth, and its ambition would be to realize that potential. In reality, "newspaper language" and its modern

\footnotetext{
${ }^{19}$ Owen, “Apologia Pro Poemate Meo,” Complete Poems, 123-24.
} 


\section{KERSHAW: POETRY AS ANTIDOTE TO TOXIC CERTAINTY}

derivatives tend to include toxic certainty in the form of ideological polemic that co-opts whatever factual content the medium does manage to provide, which is why so many of us join Sassoon in wishing it would just go away. Such a genre in its ideal as a presentation of neutral facts could not be classified in terms of pro-x and anti-y, but its real counterpart in actual news media certainly could. But the poiētai logou are too concerned with a thick, cumbersome truth occupying three dimensions. Thus, to classify a poet or her poetry in terms of its place in a discursive continuum whose limits are pro-x and anti-y is necessarily to restrict her expression to very narrow limits indeed. Siegfried Sassoon is an anti-war poet. So what is to be made with his fixation on, say, bird calls? Wilfred Owen is an anti-war poet. So what is to be made of his struggle with his sexual orientation or religious institutions and dogmas? It is an interesting fact of reception history that Owen's popularity arose from the anti-Vietnam movements of the 1960's that were more interested in co-opting the potency of Owen's linguistic imagination to speak out against the war than they were in participating in the communion of souls that his poetry offers. Since the dominant genres of certainty like "newspaper language" demand assimilation into their respective frameworks, we humans in the congregation or classroom too often find ourselves with nothing to say. Our realities, our lived experiences cannot and will not conform totally to an objectifying standard unless we force them to some degree. The greatest casualty in this progress is love, the empathy that poets of the word can create. Owen calls this potential discursive realm "the eternal reciprocity of tears." ${ }^{20}$ Consider the following letter from Owen to his mother in the last six months of his life:

For 14 hours yesterday I was at work - teaching Christ to lift his cross by numbers, and how to adjust his crown; and not to imagine he thirst till after the last halt; I attended his Supper to see that there were no complaints; and inspected his feet to see that they should be worthy of the nails. I see to it that he is dumb and stands to attention before his accusers. With a piece of silver I buy him every day, and with maps I make him familiar

\footnotetext{
${ }^{20}$ Cf. Owen, "Insensibility;" Complete Poems, 145-47.
} 


\section{KERSHAW: POETRY AS ANTIDOTE TO TOXIC CERTAINTY}

with the topography of Golgotha. ${ }^{21}$

Obviously Owen fits the definition of "poet" or "maker" of the word in its most literal sense, but here he illustrates the discursive space occupied by poiētai logou in their more complete roles as ministers of the Gospel. Occupying the morally problematic space of small unit commander, Owen meditates on the sacred nature of humanity by imagining every mundane encounter with the common soldier as an encounter with Christ. His own attitude lies somewhere between admiration and adoration, and he wrestles with his awareness that he is partly to blame for the suffering of these demi-Christs.

Heart, you were never hot

Nor large, nor full like hearts made great with shot;

And though your hand be pale,

Paler are all which trail

Your cross through flame and hail:

Weep, you may weep, for you may touch them not. ${ }^{22}$

For both Owen and Sassoon - and indeed for many poets and potentially all of us as poiētai logou — ideology, dogma, and their presumed certainties are a distant second priority to mediating the sacred word of humanity: God's own image. The intimate realities of suffering, of fear, of weeping, and of love are the primary realities of the Gospel. Any serious commitment to the Gospel must not contain these things, but rather be subsumed beneath them. Owen's work and the development of his worldview in the last few months of his life is a good example of how this can be achieved. Owen is frequently referred to as "the poet of pity," but Owen himself asserted not that there was pity in his poetry, but rather that his poetry existed in pity. ${ }^{23}$ The intense reality of

${ }^{21}$ Wilfred Owen "Letter to Susan Owen, July 4, 1918," in Collected Letters of Wilfred Owen, ed. Harold Owen and John Bell, (London, Oxford University Press, 1967), 562.

22 Wilfred Owen, "Greater Love," Complete Poems, 166-167.

${ }^{23}$ Wilfred Owen, "Preface," Wilfrid Owen: Complete Poems and Fragments, Vol. 2, ed. Jon Stallworthy (London, Chatto \& Windus, 2013), 535-536. 


\section{KERSHAW : POETRY AS ANTIDOTE TO TOXIC CERTAINTY}

human experience was not a derivative fact that one could abstract from his own attempts at wordmaking. It was the primary fact within which his entire worldview, ethical scheme, and literary productivity operated. And this worldview tended to work from a few foundational assumptions, the main being the irreducible divinity inherent in human being, human suffering, and human love. The final line of the above quoted stanza from Owen's poem “Greater Love” clearly references the sacred body of God the Son, who commanded Mary to "Touch me not (John 20:17, KJV)," until after rising to the Father. Owen renders the apparently meaningless suffering of soldiers both British and German meaningful in an absolute sense. In this act of Gospel word-making, absolute truth is pulled from ideology or the realm of propositions which presuppose a degree of certainty and placed instead in the sphere of a bodily, love-based kind of reciprocal knowing. Alternate formulations of the love might be something akin to reverence, or adoration.

In the spirit of nourishing poetry in the stead of toxic certainty, allow me to make a poetic theological suggestion with a broad zone of connotative possibility, rather than a dogmatic assertion. That way we can revel in poetry's liberality in giving edifying space to the imagination. The suggestion is this: isn't the priority of lived experience in all its grotesqueries somewhere near the heart of incarnational theology? The poetic formulations that open John's Gospel suggest a meeting point of the activity of word making and incarnation - The Word made flesh. This wordmaking entails an omnipotent God condescending to the limited sphere of human being. This event stands outside the binaries set up by the certainties of explicit law and covenant that began at Sinai and its long, complex, and venerable exegetical history. The Incarnation suggests that these efforts, while diligent, thorough, voluminous and well intentioned, were in fact insufficient. Nonetheless, there were limitations not to the effort of developing an all-encompassing religious law and practice, but to its genre and the inherent certainties bound up in that genre. God therefore 


\section{KERSHAW : POETRY AS ANTIDOTE TO TOXIC CERTAINTY}

appeared and endured as a made Word, hallowing and redeeming the human experience by becoming flesh and dwelling among us. God, understood as the product of word-making, lived a transcendent reality outside the constraints of binary constructs of certainty, many of which were hostile and violent to God's transcendent posture and commitment to the ineffable reality of love. I am not saying that Jesus was a poem, but I am suggesting a parallel: what poetry is to language, the Incarnation is to religion. The word-making is a move toward Gospel consubjectivity, perhaps even consubstantivity; it allows the space for healing and liberating imagination rather than the constricting rage and despair of toxic certainty. The word we make, much like the made Word in Christ, can thus move among the infinitely complex field of lived human experience: to mourn, to rejoice, to fear, to love, to rage, to laugh, and to die. It is in the intimacy of living and loving as poiētai logou that we bridge the gap between the enforced aloofness inherent in the genres of preaching and scholarship. Let us, therefore, reverence the infinite words made flesh, who we dwell among, and who dwell among us. 


\section{Bibliography}

Brewster, Scott. Lyric. New York: Routledge, 2009.

Graves, Robert. Good-bye to All That. New York: Vintage International, 1998.

Owen, Wilfred. “Apologia Pro Poemate Meo." In Wilfred Owen: The Complete Poems and Fragments Vol. 1, edited by Jon Stallworthy, 123-24. London: Chatto \& Windus, 2013.

—. "The Calls." In Wilfred Owen: The Complete Poems and Fragments Vol. 1, edited by Jon Stallworthy, 162-63. London: Chatto \& Windus, 2013.

—_. "Greater Love." In Wilfred Owen: The Complete Poems and Fragments Vol. 1, edited by Jon Stallworthy, 166-67. London: Chatto \& Windus, 2013.

_. "Insensibility." In Wilfred Owen: The Complete Poems and Fragments Vol. 1, edited by Jon Stallworthy, 145-47. London: Chatto \& Windus, 2013.

_. "Preface." In Wilfred Owen: The Complete Poems and Fragments Vol. 2, edited by Jon Stallworthy, 535-36. London: Chatto \& Windus, 2013.

- Wilfred Owen to Susan Owen, July 4, 1918. In Collected Letters of Wilfred Owen, edited by Harold Owen and John Bell. London: Oxford University Press, 1967.

Sassoon, Siegfried. "Attack." In Siegfried Sassoon: Collected Poems 1908-1956, 65. London: Faber \& Faber, 2002.

— . "Lines Written in Anticipation of a London Paper Attaining a Guaranteed Circulation of Ten Million Daily.” In Collected Poems 1908-1956, 121-23. London: Faber \& Faber, 2002.

—_. "Prelude: The Troops." In Siegfried Sassoon, Collected Poems 1908-1956, 61. London: Faber \& Faber, 2002.

—. Sherston's Progress: The Memoirs of George Sherston. New York: Penguin, 2013. 